\title{
TÉVŲ ŽINIOS APIE SEKRETO IŠSIURBIMĄ IŠ TRACHEOSTOMOS VAMZDELIO, SLAUGANT VAIKĄ NAMUOSE
}

\author{
Rasa Juozapavičiene $\dot{e}^{1}$, Silva Kostyliovienè $\dot{e}^{1,2}$, Odeta Inputaite் ${ }^{1}$, Dovilè Grinkevičiūtè $\dot{2}^{2,3}$ \\ ${ }^{1}$ Kauno kolegijos Medicinos fakulteto Slaugos katedra, \\ ${ }^{2}$ Lietuvos sveikatos mokslu universiteto ligoninès Kauno kliniku \\ Vaiku intensyviosios terapijos skyrius, \\ ${ }^{3}$ Lietuvos sveikatos mokslu universiteto Medicinos fakulteto Vaiku ligu klinika
}

Raktažodžiai: tèvų žinios, vaiko slauga namuose, tracheostomos vamzdelis, sekreto išsiurbimas.

\section{Santrauka}

Vaikų, sergančių lètinèmis ligomis ir (arba) negalių ar turinčių specialiujų sveikatos poreikių, gydymas, slauga ir priežiūra reikalauja daug sveikatos priežiūros sistemos išteklių, todèl daugejja vaikų, gyvenančių ir slaugomų namuose. Siekiant užtikrinti namuose slaugomų vaikų gyvybines funkcijas, pagerinti jų gyvenimo kokybę ir išvengti komplikacijų, gali būti suformuojama tracheostoma, taikoma deguonies terapija, netgi dirbtinè plaučiu ventiliacija (DPV). Ligonine, vaikų intensyviosios terapijos ar vaiku skyrius nèra skirti šeimoms ir neorientuoti ị vaiko raidą, mokymąsi ar šeimos socialinị gyvenimą, todèl vaikai, kuriems suformuota tracheostoma, gali būti slaugomi ir prižiūrimi namuose. Vaiko, kuriam suformuota tracheostoma, išvykimas iš ligoninès ị namus reikalauja specialių technologijų, finansinių išteklių, šeimos ir bendruomenès slaugytojų mokymų bei pirminès sveikatos priežiūros ir kitų specialybių sveikatos priežiūros specialistų gebejjimo rūpintis vaiku. Tèvai turi prisiimti atsakomybę už kompleksinių vaiko priežiūros poreikių patenkinimą. Vaikų, kuriems suformuota tracheostoma, slauga namuose yra labai sudètingas procesas, kadangi netinkama priežiūra ar slaugymo klaidos gali kelti pavojų vaiko sveikatai ir gyvybei. T. Karaca (2016) teigia, kad tracheostomos priežiūra apima ne tik gleivių išsiurbimo procedūrą, vamzdelių valymą ir keitimą, tvarsčių keitimą, tačiau ir infekcijos bei kitų komplikacijų prevenciją bei gydymą, oro drékinimą, vaiko mitybą ir kitus slaugos aspektus. Nuo technologijų priklausomi vaikai gali būti saugiai prižiūrimi namuose, tačiau šeimos nariai turi būti išmokyti vaiko priežiūros, turèti reikiamų priemonių bei įrangą ir gauti socialinę paramą. Tyrimais įrodyta, jeigu tèvai yra tinkamai apmokyti, vaiko slauga namuose gali būti kokybiška, išvengiant neigiamų padarinių vaiko sveikatai ir gyvybei.

Tyrimo tikslas - atskleisti tẻvų žinias apie sekreto išsiurbimą iš tracheostomos vamzdelio, slaugant vaiką namuose.

Tyrimas buvo vykdomas 2019 m. lapkričio mèn. socialiniame tinkle „Facebook“ esančioje grupèje „Vilties spindulèlis“. Tyrime dalyvauti buvo pakviesti tèvai, auginantys ir slaugantys namuose vaiką, kuriam suformuota tracheostoma. Buvo naudojama kiekybinè tyrimo strategija ir vykdoma anketinè apklausa. Tyrime dalyvavo 24 respondentai.

Tyrimo rezultatai atskleidè, kad pusè tėvų savo žinias apie tracheostominio vamzdelio priežiūrą vertina puikiai, daugiau nei trečdalis - gerai ir tik maža dalis - vidutiniškai. Tẻvams trūksta žinių apie taisyklingą sekreto išsiurbimą iš tracheostominio vamzdelio, apie sekreto siurbimo slègio parinkimą pagal vaiko amžių, apie sekreto išsiurbimo laiką ir dažnį. Nemaža dalis respondentų žino, kad esant tirštam sekretui, galima naudoti $\mathrm{NaCl} 0,9 \%$ tirpalą.

\section{Ivadas}

Vaikų, sergančių lètinėmis ligomis ir (arba) negalių ar turinčių specialiujų sveikatos poreikių, gydymas, slauga ir priežiūra reikalauja daug sveikatos priežiūros sistemos išteklių, todèl daugejja vaikų, gyvenančių ir slaugomų namuose $[1,2]$. Mokslininkai vaiką, turinti specialiujjų sveikatos poreikių (CYSHCN - children and youth with special health care needs), apibrèžia kaip vaiką, sergantị lètine liga ar padidejjusios rizikos ja sirgti, kuriam dèl fizinès, vystymosi, 
elgesio ar emocinès būklès reikalingos sveikatos priežiūros ir susijusios paslaugos arba sveikatos priežiūrai skirta suma didesnè, nei reikalinga vaikams ịprastai [3,4]. Dažniausiai šie vaikai turi didelių sveikatos sutrikimų: kvèpavimo sistemos, neurologinių, nervų ir raumenų ligų, igimtų anomalijų [5], kuriems siekiant užtikrinti gyvybines funkcijas, pagerinti gyvenimo kokybę ir išvengti komplikacijų, gali būti suformuojama tracheostoma, taikoma deguonies terapija, netgi dirbtinè plaučių ventiliacija (DPV) $[5,6]$.

Tracheostoma - tai trachejoje chirurginiu būdu suformuota anga kakle, $\mathfrak{i}$ kurią įstumiamas specialus vamzdelis [7-9]. Dažniausios indikacijos tracheostomai yra ūminis ar lètinis kvèpavimo nepakankamumas, kuomet numatoma ilgalaikè DPV, viršutinių kvėpavimo takų obstrukcija, gausus kvejpavimo takų sekretas [6]. N. Cheung ir L. Napolitano (2014) teigia, kad dažniausiai praktikoje pasitaikančios tracheostomos suformavimo indikacijos yra šios: $2 / 3$ atveju sudaro kvėpavimo nepakankamumas ir ilgalaikès DPV poreikis, kiek mažiau atvejų sudaro neurologinès būklès, kurių metu sutrikus kvejpavimo gyvybinei veiklai reikalingas atviru kvėpavimo takų palaikymas ir ilgalaikė DPV, o trečia - viršutinių kvėpavimo takų obstrukcija, kuri iš visų šių trijų indikacijų vaikams yra kiek retesnè [10].

Lietuvoje nèra bendros sistemos registruoti vaikus, kuriems suformuota tracheostoma, tačiau LSMUL Kauno klinikose 2003-2017 m. 159 vaikams buvo suformuotos gastrostomos ir 59 tracheostomos [11]. Medicinos technologiju ir gydymo pažanga pagerino šių vaikų išgyvenamumą ir ilgalaikę priežiūrą [12], tačiau ligoninè, vaikų intensyviosios terapijos ar vaikų skyriai nèra skirti šeimoms ir neorientuoti ị vaiko raidą, mokymąsi ar šeimos socialini gyvenimą [9]. Perkeliant tokị vaiką slaugai namuose, tèvai turi prisiimti atsakomybę už kompleksinių vaiko priežiūros poreikių patenkinimą [1]. Vaiko, kuriam suformuota tracheostoma, išvykimas iš ligoninès ị namus reikalauja specialių technologijų, finansinių išteklių, šeimos ir bendruomenès slaugytojų mokymų bei pirminès sveikatos priežiūros ir kitų specialybių medikų gebejjimo juo rūpintis [9].

K. Watters (2017) teigia, kad vaikams tracheostoma suformuojama rečiau nei suaugusiems, todèl vaikų slauga namuose yra labai sudetingas procesas, kurio metu padarytos klaidos gali turèti neigiamų padarinių vaiko sveikatai ir gyvybei [6]. Ruošiantis vaiką, kuriam suformuota tracheostoma, išrašyti iš ligoninès, būtina stacionare įvertinti jo būklę ir galimybes ja pasirūpinti pačiam ar su tėvų ar globejju pagalba - vaikas neturi būti visiškai priklausomas nuo sveikatos priežiūros specialistų komandos [13]. Svarbu žinoti, kad galimos tracheostomos priežiūros komplikacijos yra hipoksija, kraujavimas, tracheostominio vamzdelio pasislinkimas, užsikimšimas ar iškritimas, žaizdos ar kvėpavimo takų infekcija, fistulių susidarymas $[6,8,9]$.

Siekiant užtikrinti kokybišką slaugą namuose ir išvengti galimų komplikacijų, būtinos moksliniais tyrimais pagrịstos tėvų žinios bei igūdžiai. K. Mai ir kt. (2020) teigia, jog prieš išleidžiant vaiką i namus, stacionaro slaugytojos moko tėvus tinkamai slaugyti vaiką, prižiūreti tracheostomą ir tracheostomini vamzdeli [14]. Lietuvos Respublikos teisès aktų nustatyta tvarka vaikai, kuriems suformuota tracheostoma ir (ar) taikoma DPV, aprūpinami visa priežiūrai namuose reikalinga medicinos įranga. 2016 m. LSMUL Kauno klinikose buvo patvirtinta „Tracheostomos priežiūros mokymo programa“, skirta tėvams. Mokymų metu tèvai praktiškai išmoksta atlikti tracheostomos priežiūrą, teikti pagalbą kritinių situacijų metu, atlikti pradini gaivinimą, naudotis reikalinga iranga [11].

T. Karaca (2016) teigia, kad tracheostomos priežiūra apima ne tik gleivių išsiurbimo procedūrą, vamzdelių valymą ir keitimą, tvarsčių keitimą, bet ir infekcijos bei kitų komplikacijų prevenciją ir gydymą, oro drékinimą, vaiko mitybą ir kt. slaugos aspektus [13]. Viena iš dažniausių procedūrų, kurias tévams tenka atlikti namuose slaugant tracheostomą turintį vaiką, yra gleivių išsiurbimas iš tracheostomos vamzdelio. Nors saugaus sekreto išsiurbimo principai yra plačiai žinomi, tačiau jų nèra griežtai laikomasi [15]. Netinkamai atliekama ši procedūra gali sukelti tokių komplikacijų kaip hipoksija, bradikardija, kraujospūdžio pokyčiai, kraujavimas [8,9], todèl rekomenduojama sekretą siurbti, esant poreikiui: kai pacientas kosi, melsvejja lūpos ir veidas, mažèja saturacija, matomas sekretas tracheostomos vamzdelyje [8,9,13,15-18]. Svarbu parinkti tinkamo diametro sekreto siurbimo kateteri - jis turètų užimti ne daugiau nei pusę tracheostomos vamzdelio diametro $[8,9,13,15-18]$. J. Greenwood ir M. Winters (2013) rekomenduoja siurbimo kateteri parinkti naudojant formulę: siurbimo kateterio dydis $\mathrm{Fr}=2 \mathrm{x}$ (tracheostomos dydis minus 2) (pvz., tracheostomos vamzdelis yra 5 numerio, tai naudojant šią formulę $2 \times(5-2)=$ rekomenduojamas 6 Fr siurbimo kateteris) [8]. Vaikams siurbimo slegis parenkamas individualiai, atsižvelgiant ị amžių: naujagimiams ir kūdikiams $-60-80 \mathrm{mmHg}(8-10 \mathrm{kPa})$, vaikams, jaunesniems nei $8 \mathrm{~m} .,-80-100 \mathrm{mmHg}(10-13 \mathrm{kPa})$, vyresniems nei 8 m. $-80-120 \mathrm{mmHg}(10-16 \mathrm{kPa})$, suaugusiesiems $-120-150$ $\mathrm{mmHg}(16-20 \mathrm{kPa})$ [9,15-18]. Rekomenduojama siurbimo trukmè yra 10-15 sekundžiu [9,15-18]. Nerekomenduojamas rutininis skysčių ịpylimas į tracheostomos vamzdelį: sterilus izotoninis $\mathrm{NaCl} 0,9$ proc. tirpalas ị tracheostomos vamzdeli pilamas tuo atveju, kai sekretas tirštas ir kemšasi tracheostomos vamzdelis [9,15-18]. I tracheostomos vamzdeli ịpilamas sterilaus izotoninio $\mathrm{NaCl} 0,9$ proc. tirpalo kiekis priklauso nuo vaiko amžiaus ir esamos situacijos - 0,1 - $1 \mathrm{ml}$ [9].

Nuo technologijų priklausomi vaikai gali būti saugiai 
prižiūrimi namuose, tačiau šeimos nariai turi būti išmokyti vaiko priežiūros, turèti reikiamų priemonių, irangą ir gauti socialinę paramą $[9,11]$. Tyrimais ịrodyta, jeigu tèvai yra tinkamai apmokyti, vaiko priežiūra gali būti kokybiška, o neigiamų padarinių vaiko sveikatai ir gyvybei gali būti išvengta [19].

Tyrimo tikslas - atskleisti tėvų žinias apie sekreto išsiurbimą iš tracheostomos vamzdelio, slaugant vaiką namuose.

\section{Tyrimo medžiaga ir metodai}

Tyrimas vykdytas $2019 \mathrm{~m}$. lapkričio mèn. socialiniame tinkle „Facebook“ esančioje grupejje „Vilties spindulèlis“. Jame dalyvauti buvo pakviesti tèvai, auginantys, prižiūrintys ir slaugantys namuose vaiką, kuriam suformuota tracheostoma. Buvo naudojama kiekybine tyrimo strategija ir vykdoma anketinè apklausa.

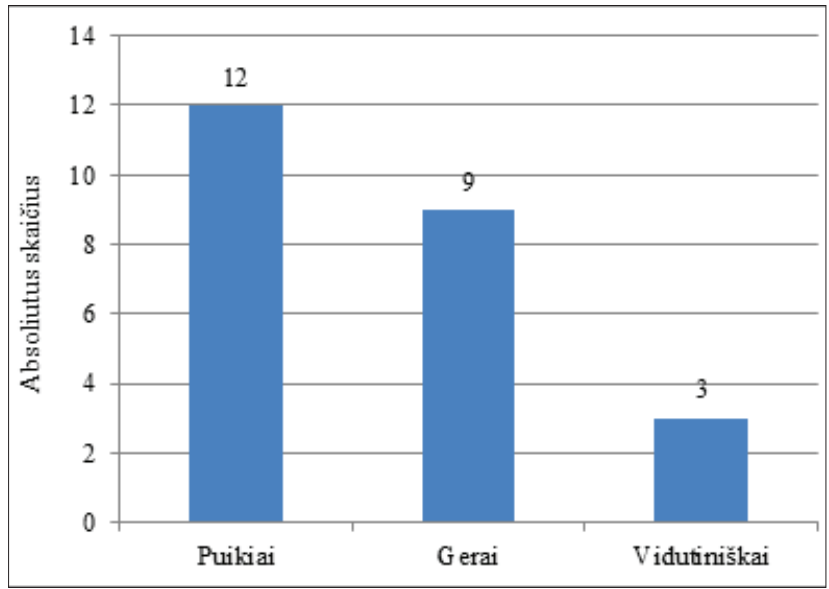

1 pav. Tẻvų žinių, susijusių su tracheostominio vamzdelio priežiūra, įsivertinimas

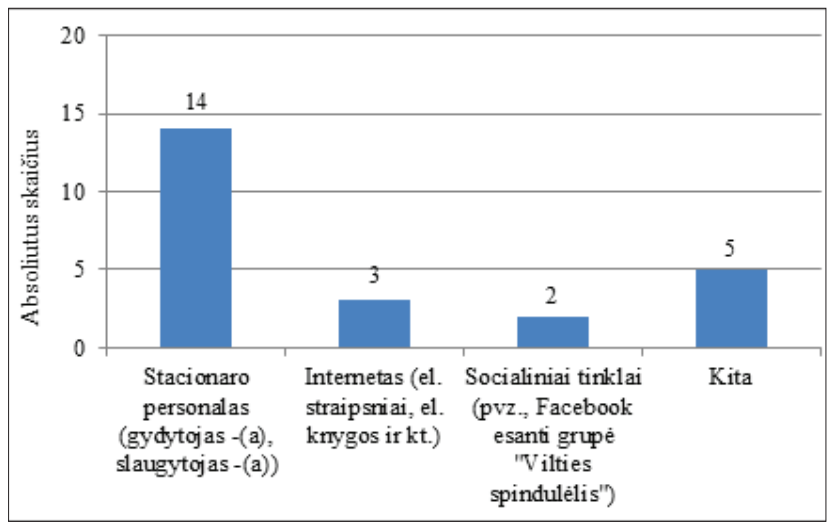

2 pav. Tẻvų žinių, susijusių su tracheostominio vamzdelio priežiūra, šaltiniai
Tyrime savanoriškai dalyvavo 24 respondentai. Analizuojant duomenis, nustatyta, kad respondentų vaikų amžius svyruoja nuo 2 iki 18 metų. 15 apklaustų tėvų namuose slaugo ikimokyklinio amžiaus (iki 7 metų) vaikus, o 9 apklaustieji - mokyklinio amžiaus vaikus (vyresnius nei 7 metų).

Tyrimui atlikti naudotas autorių parengtas klausimynas, kurị sudaro 22 klausimai, padedantys išryškinti dalyvių žinias apie vaiko, turinčio tracheostomą, slaugos ir priežiūros ypatumus. Klausimai buvo formuojami galint pasirinkti vieną tinkamą atsakymą arba kelis galimus atsakymo variantus. Anketoje užduodami klausimai apie vaiko, turinčio tracheostomą, slaugos ypatumus, klausiama, kaip vienoje ar kitoje situacijose elgiasi respondentas.

Gauti tyrimo duomenys buvo analizuojami ir apdorojami, taikant aprašomosios statistikos skaičiavimo metodą bei tyrimo duomenų statistinę ir grafinę analizę. Duomenys apdoroti naudojant Microsoft Excel ir Microsoft Word programas. Apibendrinti duomenys pateikti absoliučiais skaičiais.

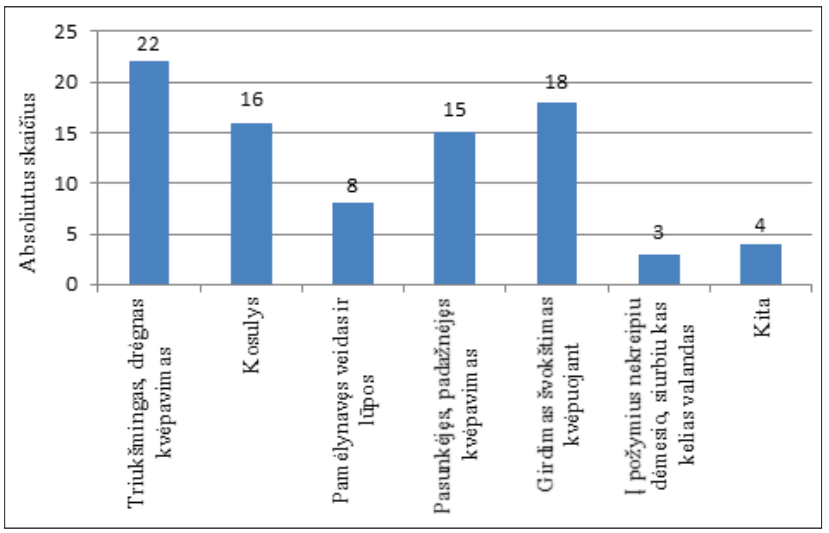

3 pav. Tẻvų žinios apie požymius, rodančius sekreto iš kvėpavimo takų išsiurbimo poreiki

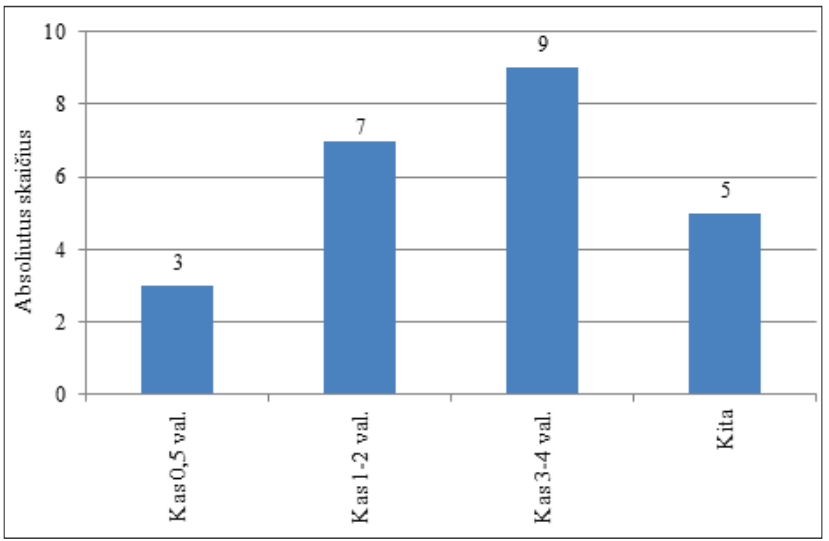

4 pav. Tèvų žinios apie sekreto išsiurbimo dažni 


\section{Rezultatai ir jų aptarimas}

Tyrimo rezultatai atskleidè, kad pusė apklaustujjų (12 respondentų) savo žinias apie tracheostominio vamzdelio priežiūrą vertina puikiai, daugiau nei trečdalis (9 respondentai) vertina gerai ir tik maža dalis (3 respondentai) - vidutiniškai. Nei vienas iš respondentų savo žinių neįsivertino patenkinamai ar blogai (1 pav.).

Tyrimo duomenimis, respondentams daugiausia žinių apie tracheostomą turinčio vaiko priežiūrą suteikè stacionare dirbantys gydytojai ir slaugytojai. Taip teigè daugiau nei pusè respondentų (14 tiriamuju), atsakydami, kad juos apie tracheostominio vamzdelio priežiūrą daugiausia mokè ir teikè žinių stacionare dirbantys sveikatos priežiūros darbuotojai. Likusi dalis respondentų teigè, kad informacijos gavo iš internetineje aplinkoje patalpintų straipsnių, e. knygų (3 respondentai) ar iš socialinių tinklų ( 2 respondentai). Tyrimo metu respondentai nurode ir kitus žinių gavimo šaltinius: „Asmeninè patirtis“, „kitos tokị pat vaiką auginančios mamos“, ,reanimacijos slaugytoja“. Tyrimo rezultatai atskleide,

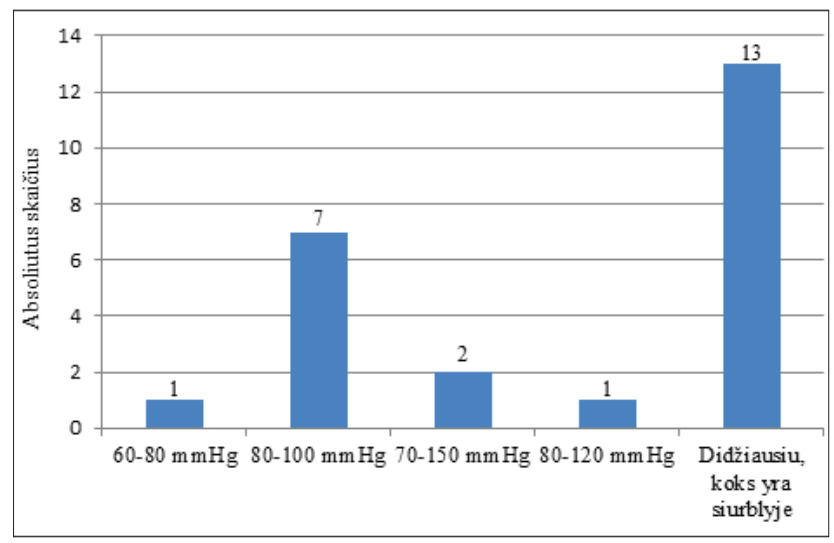

5 pav. Tẻvų žinios apie sekreto išsiurbimo slègị

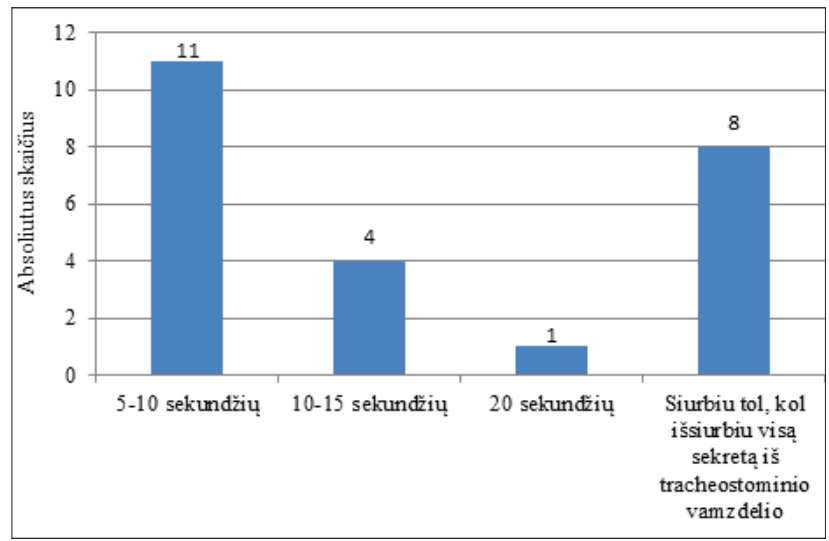

6 pav. Tėvų žinios apie sekreto siurbimo trukmę kad iš bendruomenès slaugytojo, lankančio vaiką namuose, tèvai žinių negavo (2 pav.).

Pagrindiniai simptomai, rodantys, jog pacientui reikalingas sekreto išsiurbimas iš tracheostominio vamzdelio - tai kosulys, veido ir lūpų cianozė ir pačiu pacientų prašymas išsiurbti sekretą. Kiti galimi simptomai gali būti triukšmingas ir drègnas kvėpavimas, tachikardija, pasunkèjęs ar padažnèjęs kvèpavimas, neproduktyvus kosulys, girdimas švokštimas kvèpavimo metu ir tracheostominio vamzdelio pokyčiai. Analizuojant tyrimo duomenis, atsižvelgiant i požymius, pagal kuriuos respondentai sprendžia, ar vaikui reikalingas kvėpavimo takų sekreto išsiurbimas, nustatyta, kad dauguma tėvų (22 respondentai) nurodè triukšmingą ir drègną kvėpavimą, švokštimą kvejpavimo metu (18 respondentų), kosuli (16 respondentu) ir pasunkejjusị bei padažnèjusị kvèpavimą (15 respondentų). Mažiau nei pusè respondentų pažymėjo, kad sekretą iš tracheostominio vamzdelio reikia išsiurbti tuomet, kai pastebima cianozè veide ir apie lūpas (8 respondentai). Tik labai maža dalis tyrimo dalyvių nurodè, jog sekretą siurbia, kai „,vaikas kartais paprašo pats, kad jam išsiurbtų sekretą ar moka atkosėti pats" arba į nurodytus požymius nekreipia dèmesio, o susidariusị sekretą siurbia reguliariai kas keletą valandų (3 pav.).

Tèvams, auginantiems tracheostomą turintị vaiką, būtina žinoti, jog sekretą išsiurbti reikia ne rečiau kaip kas 6-12 valandų. Tyrimo metu siekta išsiaiškinti, kaip dažnai tèvai atlieka šią procedūrą. Tyrimo rezultatai parodé, jog tèvai sekretą išsiurbia gana dažnai. Daugiau kaip pusè tèvų sekretą siurbia kas 1-2 valandas (7 respondentai) arba kas 3-4 valandas (9 respondentai). Keletas tėvų nurodè, kad tai atlieka kas 0,5 val., o likusieji atviravo, kad „kartais ir 10-20 kartų per valandą“", ,ryte dažniau kas pusvalandị, vèliau kas 1-2 val., o kai serga - kas 15 min.“, „Kai vaikas buvo dar mažas, siurbėme ištisai, o dabar tik ligos atveju“ (4 pav.).

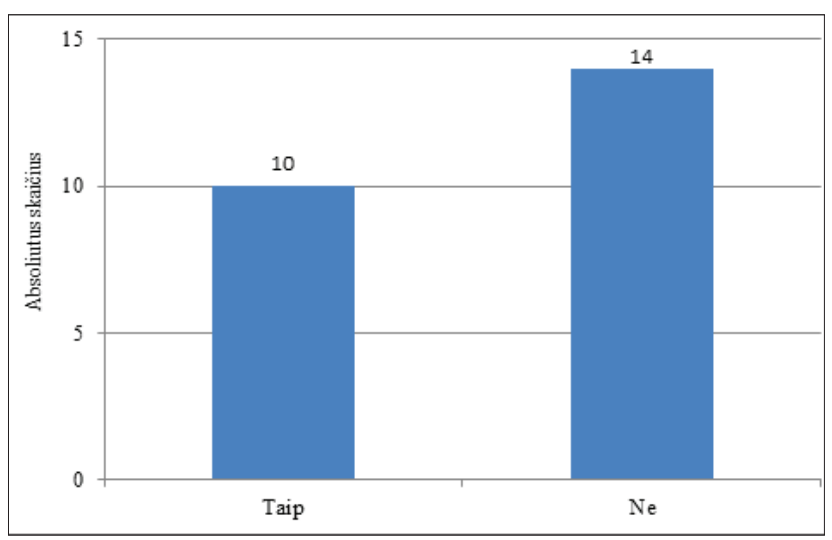

7 pav. Tèvų žinios apie $\mathrm{NaCl} 0,9$ proc. naudojimą, esant tirštoms ir tąsioms gleivèms 
Sekreto siurbimo slègis turi būti parenkamas atsižvelgiant ị vaiko amžių ir siurbimo slègị. Per didelis siurbimo slègis gali pažeisti trachèjos gleivinę, atsiranda alveolių subliūškimo rizika, skatinama bakterijų kolonizacija, todèl patariama siurbti slègiui esant iki $120 \mathrm{mmHg}$. Vertinant tèvų žinias, kokiam slègiui esant iš tracheostominio vamzdelio siurbiamas vaiko kvėpavimo takų sekretas, gauti rezultatai parodè, kad tèvai, nustatydami sekreto siurbimo slègi, nèra linkę atsižvelgti ị vaiko amžių. Daugiau nei pusè respondentų (13 respondentų) sekretą siurbia esant didžiausiam siurblio slègiui. 7 respondentai pasirinko $80-100 \mathrm{mmHg}$ slègi ir tik vienas apklausos dalyvis sekretą siurbia esant $80-120 \mathrm{mmHg}$ slègiui (5 pav.).

Rekomenduojama sekreto siurbimo trukmė yra 10-15 sekundžių, nes per ilgai užtrunkantis siurbimas trikdo kvèpavimą, didindamas hipoksijos ir bradikardijos riziką, pažeidžiama trachëjos gleivinè. Apklausos metu tėvų pasiteiravus, kiek laiko jiems užtrunka sekreto išsiurbimas iš tracheostominio vamzdelio, tyrimo rezultatai parode, kad vos mažiau nei pusė tyrimo dalyvių (11 respondentų) vieno siurbimo metu sekretą siurbia 5-10 sekundžių. 8 respondentai teigé, kad siurbia tol, kol išsiurbia visą sekretą iš tracheostominio vamzdelio, likusieji siurbia 10-15 ar 20 sekundžių (6 pav.).

Rutininis skysčiu pylimas ị tracheostomos vamzdeli nerekomenduojamas. Tyrimo rezultatai atskleidè, kad 10 respondentų nurodè, jog esant tirštoms ir tąsioms gleivèms, $\mathfrak{i}$ tracheostomos vamdeli, atsižvelgdami ị vaiko amžių, ịlašina sterilaus izotoninio $\mathrm{NaCl} 0,9$ proc. tirpalo (7 pav.).

Respondentu, atsakiusių jog naudoja $\mathrm{NaCl} 0,9$ proc., klausta, kiek mililitrų $\mathrm{NaCl}$ sulašina ị tracheostominị vamzdeli. Analizuojant tyrimo duomenis nustatyta, kad 8 respondentai ịlašina 0,5 - $1 \mathrm{ml}$, kiti teigè, kad ịlašina „kelis lašus ir tai atlieka 2-3 kartus iš eilès“.

\section{Išvados}

1. Tèvai, auginantys vaikus, kuriems suformuota tracheostoma, savo žinias apie tracheostomos ir tracheostominio vamzdelio priežiūrą, jo valymą bei tvarsčių keitimą ịsivertina skirtingai. Pusè tèvu žinias apie tracheostominio vamzdelio priežiūrą vertina puikiai, daugiau nei trečdalis - gerai, maža dalis - vidutiniškai.

2. Nustatyta, kad tėvams, prižiūrintiems tracheostomą turinčius vaikus, trūksta žinių apie taisyklingą sekreto išsiurbimą iš tracheostominio vamzdelio, apie sekreto siurbimo slègio parinkimą pagal vaiko amžių bei apie sekreto išsiurbimo laiką ir dažnį.

3. Tyrimo rezultatai parodè, kad nemaža dalis respondentų žino, jog rutininis skysčių ịpylimas ị tracheostomos vamzdelị nerekomenduojamas, tačiau esant tirštam ir tąsiam sekretui bei kemšantis tracheostomos vamzdeliui, galima naudoti $\mathrm{NaCl} 0,9$ proc. tirpalą.

\section{Literatūra}

1. Woodgate RL, Edwards M, Ripat JD, Borton B, Rempel G. Intense parenting: a qualitative study detailing the experiences of parenting children with complex care needs. BMC Pediatrics 2015;15(1):1-15.

https://doi.org/10.1186/s12887-015-0514-5

2. Russell C, MacGinley K, Meads C. Tracheostomy care in community settings. Primary Health Care 2019;29(4):40-49. https://doi.org/10.7748/phc.2019.e1548

3. Gulla KM, Sahoo T, Sachdev A. Technology-dependent children. International Journal Pediatrics Adolescent Medicine 2020;7(2):64.

https://doi.org/10.1016/j.ijpam.2019.07.006

4. McPherson M, Arango P, Fox H, Lauver C, McManus M, Newacheck PW, Strickland B. A new definition of children with special health care needs. Pediatrics 1998;102(1):137-139.

https://doi.org/10.1542/peds.102.1.137

5. Spratling R. Understanding the health care utilization of children who require medical technology: a descriptive study of children who require tracheostomies. Applied Nursing Research 2017;34:62-65.

https://doi.org/10.1016/j.apnr.2017.02.017

6. Watters K.Tracheostomy in Infants and Children. Respiratory Care 2017;62(6):799-825.

https://doi.org/10.4187/respcare.05366

7. Volsko TA, Parker SW, Deakins K, Walsh BK, Fedor KL, Valika T, et al. AARC Clinical Practice Guideline: management of pediatric patients with tracheostomy in the acute care setting. Respiratory care 2021;66(1):144-155.

https://doi.org/10.4187/respcare.08137

8. Greenwood JC, Winters ME. Tracheostomy care. In Roberts JR \& Hedges JR. Roberts and Hedges' Clinical Procedures in Emergency Medicine E-Book 2013:134-151. ISBN 978 - 14557 - $0606-8$

9. Kostyliovienė S., Vaškelytė A., Grinkevičiūtė D. Tracheostomos priežiūra. Cit. Piščalkienè V. Praktiniai patarimai tėveliams, auginantiems negalią turintị vaiką. Kaunas: Kauno kolegija. 2019:113-124.

10. Cheung NH, Napolitano LM. Tracheostomy: Epidemiology, Indications, Timing, Technique, and Outcomes Discussion. Respiratory care 2014;59(6):895-919. https://doi.org/10.4187/respcare.02971

11. Kostyliovienė S, Grinkevičiūtė DE, Vaškelytė A, Misevičienė V, Kilda A. Technology-dependent children discharge homeexperience in Hospital of Lithuanian University of Health Sciences Kauno Klinikos. International Journal Clinical Practice 2019;73(S186):14.

https://doi.org/10.1111/ijcp.13326 
12. Breneol S, Goldberg L, Watson J. Caring for Children Who Are Technology-Dependent and Their Families: The Application of Watson's Caring Science to Guide Nursing Practice. Advances in Nursing Science 2019;42(2):E13-E23.

https://doi.org/10.1097/ANS.0000000000000238

13. Karaca T. Nursing Care: Basic principles of tracheostomy care at home. International Journal of Advanced Research 2016;4(6):494-497.

https://doi.org/10.21474/IJAR01/847

14. Mai K, Davis RK, Hamilton S, Robertson-James C, Calaman S, Turchi RM. Identifying Caregiver Needs for Children With a Tracheostomy Living at Home. Clinical Pediatrics 2020;59(13):1169-1181.

https://doi.org/10.1177/0009922820941209

15. Edwards E. Principles of suctioning in infants, children and young people. Nursing Children Young People 2018;33(3).

https://doi.org/10.7748/ncyp.2018.e846_crt

16. American Association for Respiratory Care. AARC clinical practiceguidelines. Endotracheal suctioning of mechanically ventilated patients with artificial airways 2010. Respir Care 2010;55(6):758-764. https://pubmed.ncbi.nlm.nih. gov/20507660/

17. Tume LN, Copnell B. Endotracheal suctioning of the critically ill child. J Pediatr Intensive Care 2015;04(2):56. https://doi.org/10.1055/s-0035-1556747

18. Russell C, MacGinley K, Meads C. Tracheostomy care in community settings. Primary Health Care 2019;29(4):40-49. https://doi.org/10.7748/phc.2019.e1548

19. Sharma PK, Vinayak N. A single center experience of pediatric tracheostomy. Indian pediatrics 2018;55(12):1091-1092.

https://doi.org/10.1007/s13312-018-1449-3

PARENTS' KNOWLEDGE SECRETION SUCTION FROM TRACHEOSTOMY TUBE WHILE NURSING A CHILD AT HOME

\section{R. Juozapavičienė, S. Kostyliovienė, O. Inputaitė,} D. Grinkevičiūtè

Keywords: parental knowledge, nursing of the child at home, tracheostomy tube, secretion suction.

Summary

Treatment, care and support for children with chronic diseases and/or disabilities and special needs require significant resources in the healthcare system, therefore the number of such children li- ving and caring at home is increasing. For these children, tracheostoma can be formed to ensure vital functions, improve quality of life and avoid complications, some children need oxygen therapy, even mechanical lung ventilation. The hospital, pediatric intensive care unit or pediatric departments are not intended for families and do not focus on the child's development, education or family social life, so children with tracheostoma can be cared and nursed at home. The departure of a child with tracheostoma from hospital to home requires special technologies, financial resources, training of family and community nurses, as well as the ability of primary care and other specialty health professionals to take care of such a child. Parents must take responsibility for meeting complex childcare needs. Nursing children with a tracheostomy at home is indeed a very difficult process, since improper care, nursing errors can endanger not only the health of the child, but also life. Karaca (2016) states that tracheostomy care includes not only secretion suction procedure, cleaning and replacement of tubes, changing dressings, but also prevention and treatment of infection and other complications, air irrigation, child nutrition, other nursing aspects. Technology-dependent children can be safely cared for at home, but family members need to be trained in childcare, have the tools and equipment they need, and receive social support. Studies have shown that if parents are properly trained, child care can be of high quality and negative consequences for the child's health and life can be avoided.The aim of the work: to reveal the knowledge of parents about secretion suction from tracheostomy tube while nursing a child at home. The investigation was carried out in November 2019 in the group „Vilties spindulèlis” on Facebook. Parents raising and caring for a child with tracheostomy at home were invited to take part in the study. A quantitative survey strategy and a questionnaire survey were used. The survey included 24 respondents. The results of the study revealed that half of parents value their knowledge of tracheostomy tube care perfectly, more than a third of parents rate well and only a small proportion value it on average. Parents lack knowledge about the correct suction of secretions from tracheostomy tube, about the selection of secretion suction pressure according to the age of the child, about the time and frequency of the suction. A significant number of respondents know that isotonic solution can be used when secretions are thick.

Correspondence to: rasa.juozapaviciene@go.kauko.lt

Gauta 2021-11-02 